\title{
PECULIARITIES OF ENTERPRISE MANAGEMENT IN THE MARKET OF HOUSING AND UTILITIES SERVICES DURING THE REFORM OF THE INDUSTRY (EXPERIENCE OF FOREIGN COUNTRIES)
}

\begin{abstract}
Housing and communal economy (HCS) is the most important element of both social and economic sphere of the national economy, a complex multi-branch industrial and technical complex. For Ukraine, the problems of development of housing and communal services are of particular importance due to the high level of depreciation of housing stock, the critical state of utilities infrastructure, low quality of services, high resource loss. All these and other factors for many years determine the social, environmental, political and other problems of functioning of the complex, and as a consequence, have a negative impact on the livelihood of the population and the efficiency of the functioning of enterprises, including other industries. Therefore, systematization of the problems of functioning of the housing and utilities sector and the definition of possible prospects for their solution is an urgent issue in modern economic conditions.
\end{abstract}

Keywords: reform, management, local self-government, associations of co-owners of apartment buildings, housing fund.

\section{INTRODUCTION}

For many years, Ukraine has carried out global market reforms, which affected all spheres of the national economy, both material and non-material - industry, agriculture, science, education, etc. Housing and utilities, unfortunately, remain one of the most backward and inefficient sectors of the Ukrainian economy: with the huge expenditure of human, financial and material resources the quality of utilities services is unsatisfactory. But it is one of the most significant and important industries, the state of which is of huge importance on the quality of life of the entire population. In the general process of reforming the Ukrainian economy, the problem of reforming the housing and utilities sector occupies a special place. Firstly, it is one of the largest sectors of the national economy, and secondly, this industry is the most socially important. If mistakes in the reform of, for example, the

\footnotetext{
${ }^{1}$ Anna Konyev, Candidate of sciences in public administration, Heilbronn University, Reinhold Würth University, Campus Künzelsau, Institute for Digitalization and Electric Drives (IDA), Institute Assistant; e-mail: ganna.konyeva@gmail.com.

2 Olena Dolgalova, Doctor of Public Administration, Professor, Head of the Management Department, Donbas National Academy of Civil Engineering and Architecture, Ukraine (corresponding author); e-mail: elena.dolgaleva21@gmail.com. ORCID: 0000-0002-7281-2046.
} 
coal industry, will affect not directly, but indirectly and after a certain period, then any error in the reform of the housing and utilities sector will cause an immediate negative social reaction, destabilization of the political situation and unforeseen economic losses (Ломова, 2012).

Although the reform of the housing and utilities sector is currently a priority for the Ukrainian economy, most of the activities within the framework of the ongoing reform are aimed more at maintaining the current performance of the sector, rather than at its further development and improvement.

\section{RELEVANCE OF THE TOPIC}

Ukrainian housing and utilities services are in a state of severe crisis, as evidenced by the high degree of dissatisfaction of citizens, turning into housing and utilities riots. Reforming the housing and utilities services requires a comprehensive approach, systematic measures to improve the efficiency of its functioning. One of the main ways of reforms is to change cardinally the system of providing housing and utilities services, that is, the ways of managing the enterprises of this sector. An important condition for implementing the reform of housing and utilities services in Ukraine is the study of foreign experience of managing and providing housing and utilities services. This article considers the experience of development of institutions of house owners; public-private partnership; advanced training of management personnel employed in the sector; market competition in the industry (Копылов, 2008).

\section{STATEMENT OF THE PROBLEM}

The domestic practice of management of residential houses has not yet shown its effectiveness and functionality, also, the legislative framework of Ukraine does not give clear and unambiguous explanations on the issue of management of enterprises of the housing and utilities sector. To solve the problems associated with the management of the housing stock, it is advisable to turn to foreign experience, which introduces the most advanced knowledge in the sphere of industry management and regulation of relations between enterprises in the market.

The purpose of the article is to analyze the problems of management of enterprises of housing and utilities services in the conditions of reforming the industry. To solve this problem, it is necessary to analyze the experience of countries that have achieved significant results in the provision of housing and utilities services.

Issues of reforming of the sector, management of enterprises, regulation of relations between enterprises, consumers of its services and stakeholders, have long been considered by Ukrainian and foreign researchers, such as M. Lomova, V. Ignatov, S. Kirsanov, A. Kazarova, L. Bezzubko, S. Evseeva, M. Gerasimova, D. Slavata, E. Skridlovska, M. Karel.

\section{PECULIARITIES OF THE FUNCTIONING OF HOUSING AND COMMUNAL SERVICES IN UKRAINE}

Housing policy in Ukraine has undergone radical changes over the past 25 years. Its goals, principles of work, various tools and created, new sources of financing have been revised. Transformation of market conditions of management in this area continues today. Organization and management of housing construction in Ukraine since 2006 are carried 
out by the Ministry of housing and communal services. At the same time housing issues are divided between two ministries: the first one is responsible for development and implementation of state housing policy and state policy and communal services; the second one is the central body of the government for urban planning and construction. The sources of funding for housing policy in Ukraine are also the regional and local budgets, as well as state programs to support mortgage lending for young families.

In 2008, to improve the efficiency and reliability of the housing and communal services and to ensure its stable development, the Law of Ukraine "National Program of reform and development of housing and communal services" was adopted (Розпорядження КМУ «Про схвалення Концепції розвитку системи державного регулювання діяльності суб'єктів природних монополій на ринку комунальних послуг». 09.07.2008, № 932).

In particular, the program was designed to ensure the functioning and dynamic development of housing, safety, and affordability of housing for all segments of the population adequate quality and quantity, stimulating investment in housing construction, elimination of monopolization of construction, reconstruction, and maintenance of housing stock and much more.

Local self-government bodies play a significant role in the process of providing housing and communal services in accordance with the competences established by the Law No. 280/97-VR “On Local Self-Government in Ukraine". The managing subjects in the housing and communal sphere can be a state management organization, homeowner's associations, or other association of tenants. (Закон України „Про місцеве самоврядування в Україні“. Відомості Верховної Ради України (ВВР), 1997, № 24, ст.170)

In accordance with the Law of Ukraine No. 417-VIII "On peculiarities of exercising the right of ownership in an apartment building", management of an apartment building must provide favorable and safe living conditions for citizens, proper maintenance of common property in an apartment building, addressing issues of the use of said property, as well as providing utility services to citizens living in such building. (Закон України „, Про особливості здійснення права власності у багатоквартирному будинку“. Відомості Верховної Ради України (ВВР), від 14.05.2015 №417-VIII)

The presence in Ukraine of state programs for the development of the housing and utilities sector indicates that this sector is still centrally regulated by state authorities. As for the role of local governments in the implementation of state regulation in the relevant markets, despite the desire of a number of municipalities to retain their regulatory functions (mainly in tariff setting), under current conditions local authorities are not able to perform market regulation in the district heating, water supply and wastewater disposal markets for the following reasons:

1) local self-governments are owners of the respective enterprises, so as a regulator, they cannot make unbiased decisions with respect to their property;

2) local governments, having public utilities at their disposal, are not interested in the emergence of a private operator in the market (for example, in the supply of heat, water supply and sewage disposal, or in the generation of heat energy), which cannot but have an impact on regulation;

3) today for the implementation of professional regulation in the markets of district heating, water supply and sanitation, there are not enough trained specialists even for the central regulatory body, not to mention the opportunities for such regulation at the local level; 
Housing and communal services include the housing stock and utilities. The housing and utilities management system is built around the basic business processes that represent housing and utilities services to consumers. Housing and communal services are divided into collective and individual services that create a public good. Consumption of housing and communal services is essential as it is aimed at satisfaction of basic physiological needs of the population, which makes it practically impossible to completely refuse their consumption or significantly reduce its volume. Most residential and non-residential facilities need these services. This leads to a constant demand and allows us to categorize the housing and utilities sector as socially important. During the reform of the housing and utilities sector, which has been going on for more than 25 years, there have been serious institutional transformations in this sphere. However, a number of unresolved problems and new difficulties have emerged.

Table 1 groups the main problems of the housing and utilities sector and their causes. Consumption of housing and communal services is of an urgent nature, as it is aimed at meeting the basic physiological needs of the population, which makes it practically impossible to completely abandon their consumption, or significantly reduce its volume. Most residential and non-residential facilities need these services. This leads to a constant demand and allows the housing and utilities sector to be categorized as socially important. The economic potential of the housing and utility sector is great. The housing and utilities sector is an attractive economic sector in many countries. The use of market mechanisms makes investing in the housing and utilities sector profitable. The sphere of housing and communal services is very promising for the development of small business and entrepreneurship. However, in order to start a business, small businesses need the support of the authorities, including financial support.

Table 1. Main problems of the housing and utilities sector and their causes.

\begin{tabular}{|c|c|c|}
\hline Groups & Problems & Reasons \\
\hline \multirow{2}{*}{$\begin{array}{l}\text { Material and } \\
\text { technical }\end{array}$} & $\begin{array}{l}\text { Physical deterioration of fixed } \\
\text { assets of engineering systems of } \\
\text { the industry }\end{array}$ & $\begin{array}{l}\text { For decades, worn-out funds have not been } \\
\text { replaced due to lack of funding }\end{array}$ \\
\hline & $\begin{array}{l}\text { Presence of dilapidated and } \\
\text { emergency housing }\end{array}$ & $\begin{array}{l}\text { Insufficient funding for new construction, } \\
\text { inefficient use of budget funds }\end{array}$ \\
\hline \multirow[b]{2}{*}{ Financial } & $\begin{array}{l}\text { Debts of payment of housing and } \\
\text { communal services }\end{array}$ & $\begin{array}{l}\text { Insufficient funding for new construction, } \\
\text { inefficient use of budget funds }\end{array}$ \\
\hline & $\begin{array}{l}\text { Investment unattractiveness of } \\
\text { the industry }\end{array}$ & $\begin{array}{l}\text { Lack of comprehensive plans for the } \\
\text { development of municipal infrastructure Lack } \\
\text { of government support for small and medium- } \\
\text { sized businesses in the industry }\end{array}$ \\
\hline Legal & $\begin{array}{l}\text { Imperfect legal and regulatory } \\
\text { framework }\end{array}$ & $\begin{array}{l}\text { Delays by regional and local governments in } \\
\text { adapting legislation to local conditions }\end{array}$ \\
\hline Labor & $\begin{array}{l}\text { Lack of highly qualified } \\
\text { personnel in the industry }\end{array}$ & $\begin{array}{l}\text { Low wages in the industry Insufficient number } \\
\text { of educational institutions that train specialists } \\
\text { in the industry }\end{array}$ \\
\hline
\end{tabular}

The housing and utilities sector accounts for $20 \%$ of the total energy consumption, and $64 \%$ of enterprises have private and mixed ownership in the market of housing and utilities 
services. There is a positive experience of attracting small business to the sphere of housing and communal services in Ukraine. A number of cities have converted certain services to the full payment by the population, which is attractive to private enterprises. This is especially true for the collection, transportation and recycling of solid domestic waste.

The efficiency of enterprises in the field of housing and utilities services, determined by a set of indicators, which include the quality of their services, resource conservation, effective financial management etc. is an important element of the development of a modern economy. In the course of work housing and utilities, enterprises face many difficulties, among which domestic researchers single out problems associated with the provision of quality services in the current economic environment, the lack of competent management, and the low level of legal and professional literacy of both owners and staff etc. (Евсеева, Герасимова, 2012).

However, the existence of several problems highlighted by domestic researchers often complicates enterprise management in the housing and utilities sector. The main problems faced by managers in the sector include:

1. Lack of qualified personnel, both managerial and manual laborers;

2. Low level of competition among companies, and a lack of serious control, which often results in an unsatisfactory quality of services;

3. Lack of strict and effective control mechanisms over the management companies, and thus, lack of consumers' influence on the companies in this field;

4. Unattractiveness of the sector for private investments due to a long payback period. (Хайруллина, Шакирова, \& Зиннуров, 2014).

\section{FEATURES OF THE FUNCTIONING OF HOUSING AND COMMUNAL SERVICES IN THE WORLD}

The existing approaches to management of housing and utility services abroad basically boil down to the fact that municipal authorities regulate the work of private enterprises and protect the rights of the population and guarantee high-quality and uninterrupted services.

In such countries as the USA, Sweden, Finland, Germany, Poland, England management of housing and utilities sector is a kind of business. Management is carried out by management companies, which are remunerated for their work. The homeowners' association (association or partnership) is responsible for the maintenance of the building to the owners. (Deutsch-Tschechische Industrie- und Handelskammer. Zielmarktanalyse 2020 mit Profilen der Marktakteure. 01.07.2020). Table 2 shows the peculiarities of housing and communal services management in foreign countries. (Кицай, 2012).

Table 2 shows that abroad the forms of management of housing and communal services are very diverse. From the conclusion of individual contracts of each resident of an apartment house, or all residents of one house with different suppliers of resources, as in England and Germany, to the management of the sphere of housing and communal services with $100 \%$ municipal capital as in Poland.

Thus, having analyzed the situation with reform of the sphere of housing and communal services in different countries of the world it is possible to note that everywhere there was a privatization of the housing stock. The share of homeowners in the countries of Europe is from 50 to $80 \%$. As for the United States, the share of homeowners is about 70 percent. If there are owners, there is a market for the provision of public services, which should meet the growing demand for high-quality services from homeowners. In some countries in 
Europe and especially in Central Europe, the share of tenants is still large. In Scandinavia, this share is between 13-20\%. In the U.S. about 30\%. There is, however, a gradual tendency towards a decrease in their share. In socially oriented countries and countries of the former socialist camp, there is still municipal ownership of housing. Such housing is found in Sweden and the CE countries. Its share ranges from 3 to $18 \%$. Such housing is mainly used for low-income groups of the population. As for management of housing and provision of housing and communal services, during the reform, it is carried out mainly with the help of management companies and homeowners themselves. And in the countries of Europe preference is given to the latter. Their share is about $70 \%$ in Finland.

Table 2. Features of management of housing and communal services in foreign countries

\begin{tabular}{|c|c|c|}
\hline Country & Peculiarities of housing and utilities management & Result \\
\hline Sweden & $\begin{array}{l}\text { Existence of unions or associations of tenants who monitor the } \\
\text { quality of housing services. Influence political parties have } \\
\text { regional and local branches Existence of two models of } \\
\text { payment for services: } \\
\text { 1. "Discount model" - choosing and paying only for the } \\
\text { services that the tenant needs. } \\
\text { 2. The "depreciation model" - reduction of fees for services in } \\
\text { case of careful handling of the property. Existence of a } \\
\text { housing court. }\end{array}$ & $\begin{array}{l}\text { Ensuring } \\
\text { transparency of } \\
\text { management } \\
\text { structures and } \\
\text { tariffs, suppressing } \\
\text { corruption }\end{array}$ \\
\hline Germany & $\begin{array}{l}\text { Each apartment building is managed independently. It has its } \\
\text { own "coffers", the number of contributions to which is } \\
\text { determined at the general meeting. For cleaning and } \\
\text { maintaining cleanliness residents can hire a manager, but his } \\
\text { services are paid for additionally. Each apartment owner } \\
\text { concludes a contract with a supplier of resources - water, } \\
\text { electricity, gas. Heating for each house is autonomous - the } \\
\text { construction of a boiler room (boiler room). }\end{array}$ & $\begin{array}{l}\text { Full autonomy of } \\
\text { residents, } \\
\text { minimizing costs }\end{array}$ \\
\hline USA & $\begin{array}{l}\text { There is a broad market for highly specialized services in the } \\
\text { maintenance and repair of housing and maintenance of } \\
\text { engineering networks and facilities. There is a need for highly } \\
\text { skilled management and knowledge of the contracting market } \\
\text { and technology. Each state has its own routines. Money for } \\
\text { utility bills is automatically deducted monthly from the bank } \\
\text { account. Housing tax in the U.S. is levied annually and is 13\% } \\
\text { of the market value of the property. }\end{array}$ & $\begin{array}{l}\text { A highly } \\
\text { specialized market } \\
\text { for utilities. The } \\
\text { absence of rent as } \\
\text { such. }\end{array}$ \\
\hline England & $\begin{array}{l}\text { The existence of only private companies - suppliers of } \\
\text { resources. Each resident chooses their own resource provider, } \\
\text { and can change them if necessary, but no more than once a } \\
\text { week. Resource providers can be different, for example, one } \\
\text { sells electricity during the day and another at night. }\end{array}$ & $\begin{array}{l}\text { Independent } \\
\text { sourcing of } \\
\text { resources to } \\
\text { minimize rent }\end{array}$ \\
\hline Poland & $\begin{array}{l}\text { The housing and utilities sector is managed by a joint-stock } \\
\text { company with } 100 \% \text { state (municipal) capital. All types of } \\
\text { public utilities are combined into a single state-owned } \\
\text { company. It manages finances, resource production and } \\
\text { monitoring. Suppliers of resources may have different forms } \\
\text { of ownership. }\end{array}$ & $\begin{array}{l}\text { Providing quality } \\
\text { services. Ensuring } \\
\text { reliable operation of } \\
\text { the housing and } \\
\text { utilities sector }\end{array}$ \\
\hline
\end{tabular}


Table 2 (cont.). Features of management of housing and communal services in foreign countries

\begin{tabular}{|c|l|l|}
\hline Country & \multicolumn{1}{|c|}{ Peculiarities of housing and utilities management } & \multicolumn{1}{c|}{ Result } \\
\hline Finland & $\begin{array}{l}\text { The association of houses into joint-stock companies, 70\% are } \\
\text { managed by management companies (MC), 30\% - } \\
\text { independently. The MC is responsible for the daily } \\
\text { management under a management contract. The contract } \\
\text { contains a list of services, their rates and conditions of } \\
\text { provision. The MC chooses the operating organizations to } \\
\text { provide different kinds of services. Operating organizations } \\
\text { provide housing and communal services independently or } \\
\text { under contracts with specialized firms (repair and construction, } \\
\text { landscaping, security, garbage collection, etc.). The operating } \\
\text { organization reports annually to the residents on revenues and } \\
\text { expenditures. In large cities, utility systems are in municipal } \\
\text { ownership. Heating and water supply are centralized. Power } \\
\text { plants may be privately owned. }\end{array}$ & $\begin{array}{l}\text { Minimization of } \\
\text { costs and } \\
\text { application of } \\
\text { advanced } \\
\text { technologies (e.g., } \\
\text { availability of } \\
\text { backup oil stations } \\
\text { during periods of } \\
\text { low temperatures (- } \\
\text { 30 C) and the use } \\
\text { of secondary heat } \\
\text { from homes) }\end{array}$ \\
\hline
\end{tabular}

In all European countries during the reform of the housing and utilities sector there was a sharp increase in tariffs, in Eastern Europe they increased by more than 10 times. In the countries of Western Europe, the growth correlated mainly with the growth of energy prices and inflation and was about 2-3 times. It should be noted that sharp growth of tariffs was observed in the case of state and not always effective regulation. In Western Europe and the United States, tariffs are set in a decentralized manner, mainly by the organizations providing services in the field of housing and public utilities. (Brauer, 2003).

Many countries use public-private partnerships and concession agreements between private firms and municipal authorities to reform the housing and utilities sector. Concession agreements exist not only in the maintenance of infrastructure, but also in the construction of houses. The British and German models of housing and utilities management are somewhat different from other countries. Here all the systems of life support of the population have been transferred to private hands.

The analysis allowed us to group the common problems of management of housing and communal services in Ukraine and abroad. The solution of these problems will depend on the modernization of existing business processes.

In Europe, the management of housing and communal services is regarded as a separate business activity. In this case, the responsibility for the key management decisions in this area is vested in the association of homeowners, who are entitled both to sign a contract with a management company and to independently resolve all issues arising in the operation of housing. This increases the role of personal responsibility of each citizen for the condition of housing. In contrast to Ukraine, where the same attempt was made to delegate the responsibility for maintenance of premises, in most European countries the obligation of citizens to join homeowners' associations simultaneously with the purchase of real estate is legislatively fixed. This also leads to the fact that among contractors there is a growth of companies with highly specialized activities (for example, companies specializing only in the repair of engineering networks), allowing them to provide better services to the population, as well as to reduce costs (Васильева, 2006). 
In most European countries, such as France, the Czech Republic, Slovakia, etc., management in the field of housing and utilities services is considered a separate type of business activity for which the management organization is paid by the premise's owners, and the liability to the owners for the maintenance of the building is borne by the homeowners' association. It should also be emphasized that the approach to the management of apartment buildings, which is followed by managers in most Western countries, is based on the fact that the management organization works based on an agreement with the association of homeowners, and not with individual owners.

To improve the economic efficiency of activities, service organizations in Eastern Europe have divided into more specialized organizations. Thus, market development goes in the direction of increasing competition between organizations with the same specialization, for example, maintenance of internal house heating is carried out by one company, maintenance of metering devices on heating systems - by the second company. Accordingly, the manager should know the contractor market, the advantages of the use of various technologies, be familiar with the prices, have different tools for financing, and act as a consultant of homeowners on these issues. The separation of management of apartment buildings into an independent type of activity contributes to the increase of proposals from professional managers and the formation of a competitive market of management services, the development of small and individual entrepreneurship in the field of management of housing.

An important feature of the legal regime of real estate in apartment buildings is that all owners of residential premises, along with the premises they own, own a share of the common property in the apartment building. The law establishes strict requirements for the owner to bear the obligatory common expenses on the maintenance of the common property in the apartment building. The burden of maintenance means not only bearing obligatory expenses, but also the duty of the owner to take measures to ensure safety, security, technical serviceability, and proper sanitary condition of the common property in the apartment building. The owner must make decisions and take care of the organization of the maintenance of the building. If the house does not meet legally established requirements for the safety and quality of residential real estate, all premises' owners in the house are equally responsible to state supervisory bodies (Ломова, 2012).

In Ukraine, the emergence of housing associations as well as housing management companies largely depends on the policies of local governments. It depends on them, first of all, whether equal conditions will be created for access to the market of housing services provider for enterprises of different organizational-legal forms of ownership (Копылов, 2008).

Interaction between municipal organizations and private companies can and should be conducted in a way that promotes reasonable competition. For example, when contracting out part of the scope of certain work, the municipal service is forced to enter into a competitive struggle with a private company. A positive effect can be achieved if the municipal organization only takes on the role of the developer of the terms of reference and the controller, monitoring compliance with the terms of the contract. However, in this case, the increase in productivity will occur only if the competition among private firms is high and there is no corruption (Васильева, 2006).

Public-private partnership in various infrastructure spheres has shown its high efficiency, which determines the feasibility of using its models in the process of improving the organizational and legal forms of relations between municipal governments and public 
utilities. Thus, the experience of other countries shows a variety of forms of management of public infrastructure enterprises, allowing them to rationally distribute responsibilities and risks between the municipal and private businesses. The large-scale and complexity of the solution of economic, social, and other problems of management of housing and utilities services in Ukraine requires a comprehensive approach, the effective use of accumulated foreign experience, and its adaptation to the prevailing socio-economic and political conditions.

\section{PROPOSALS FOR REFORMING THE MANAGEMENT PROCESS OF HOUSING AND COMMUNAL ENTERPRISES IN UKRAINE}

Summarizing the diversity of theoretical knowledge and practical experience in the management of housing in developed countries, the following directions for reforming the management of housing and utilities enterprises in Ukraine can be proposed:

1. A change in the mentality of homeowners, who perceive the maintenance of their housing stock as a burden of costs, while in most Western countries, citizens regard the purchase of housing ownership as an investment (investment) and understand maintenance as an activity that ensures the safety and proper condition of the property.

2. Transition to highly specialized service of apartment buildings. In the world practice of management of apartment buildings, the approach where the owners make management decisions within the framework of the association created by them a legal entity, and the execution of decisions are entrusted to a professional management organization based on the contract is most often used. This approach to the management of apartment buildings can be considered the best because management activities are carried out on a professional level, the quality of services corresponds to the needs and capabilities of homeowners, and the democratic norms of making management decisions by homeowners are respected. Also, an advantage for homeowners when creating a partnership is the possibility to control the spending of their funds (Игнатов, 2004). In Ukraine, it is characteristic that private housing organizations seek to provide the entire range of services for the management, maintenance, and repair of apartment buildings on their own. Such universality of management organizations leads to a significant deterioration in the quality of housing and utilities services.

3. Insurance of the activities of management companies. In most countries management in the field of housing and utilities services is considered to be a separate type of business activity that requires risk insurance. The market of housing and utilities services forms requirements to management companies, noncompliance with which makes a company uncompetitive. First of all, this applies to the insurance by the managing company (manager) of its civil and material responsibility arising if improper actions of the manager caused damage to the homeowner's property, which is especially developed in most countries of Europe and America. The introduction of this approach in the legislation of Ukraine will dramatically change the situation with the quality of housing and communal services (Кирсанов, 2011).

4. Information openness and transparency of management companies. The main complaints of Ukrainian citizens to management companies are related to a lack of 
understanding of what constitutes tariffs for housing and utility services and how the cost of these components is calculated. Many people state regular unreasonable overpricing of tariffs by management companies directly in the payment documents. In this case, the experience of Finland and France, where information technology is an important component of public services, is useful. The collection and processing of information and the interaction of utilities (Brauer, 2003) companies with consumers and government agencies are automatic. In general, the entire process of personal interaction between the consumer and the service provider can take place via the Internet or other information resources (Казарова, 2015).

Thus, to solve the system problems in the sphere of provision of housing and utilities services in Ukraine, it is useful to study the positive international experience tested over time. At the same time, it is possible to build its unique model of management of multifamily residential buildings, which will be based on the best foreign analogs, but take into account the specifics and characteristics of the Ukrainian housing and utilities economy.

\section{CONCLUSIONS}

Although most enterprise management problems in the housing and utilities sphere must be solved at the legislative level, several points can be implemented by the enterprises already today. For instance, looking for contractors with narrower specialization, simplification of requirements for contractors to participate in tenders, looking for personnel with higher education and taking into account the personal qualities of the employee, interaction with educational institutions directly to attract potential employees, or formation of a new relationship with entrepreneurs who rent premises in apartment buildings.

\section{REFRENCES}

Васильева, Н. В. (2006). Механизмы предоставления жилищно-коммунальных услуг в системе муниципального управления. СПб: «Петрополис».

Brauer, K. (2003). Immobilienprojektentwicklung [In:] B. KU, Grundlagen der Immobilienwirtschaft. Wiesbaden: Gabler Verlag.

Deutsch-Tschechische Industrie- und Handelskammer. Zielmarktanalyse 2020 mit Profilen der Marktakteure. 01.07.2020. (n.d.). Access on the internet: https://www.german-energysolutions.de/GES/Redaktion/DE/Publikationen/Marktanalysen/2020/zma-tschechien-2020energieeffizienz.pdf?_blob=publicationFile \& $v=4$.

Евсеева, С. А., \& Герасимова, М. М. (2012). Управление взаимоотнотениями с заинтересованными сторонами в менеджменте качества управляющих организаиий в сфере ЖКХ. In Экономические науки.

Хайруллина, В., Шакирова, С. М., Зиннуров, Р. Р. (2014). Системный подход к решению проблем в сфере ЖКХ. "Экономика", №. 1 (7). Вестник УГНТУ. Наука, образование, экономика.

Игнатов, В. (2004). Зарубежный опыт местного самоуправления и его реформирования. Ростов н/Д: Изд- во СКАГС.

Казарова, А. (2015). Личензирование управляющих компаний как мера повышения качества услуг сферы ЖКХ. Современные проблемы гуманитарных и естественных наук 
материаль $X X V$ международной научно-практической конференции. Научноинформационный издательский центр «Институт стратегических исследований».

Кицай, Ю. А. (2012). Роль управляющих компаний в жилищно-коммунальном хозяйстве: зарубежный и отечественный опыт [In:] Кицай Ю. А., Теория и практика общественного общественного развития.

Кирсанов, С. (2011). Зарубежный опыт управления многоквартирными домами. "ЖКХ: журнал руководителя и главного бухгалтера", №.10.

Копылов, В. В. (2008). Отечественный и зарубежный опыт реформирования ЖКХ. "Гуманитарные науки. Экономика". Вестник ТГУ, выпуск 1 (69).

Ломова, М. Н. (2012). Опыт зарубежных стран в решении проблем управления жильм фондом в России [In:] Экономическая наука и практика: материаль I Междунар. науч. конф. (г. Чита, февраль 2012 г.). Чита: Издательство Молодой ученый.

Розпорядження КМУ «Про схвалення Концепції розвитку системи державного регулювання діяльності суб'єктів природних монополій на ринку комунальних послуг». 09.07.2008, № 932. (n.d.). Access on the internet: https://zakon.rada.gov.ua/laws/show/9322008-p\#Text.

Закон України „Про місцеве самоврядування в Україні“. Відомості Верховної Ради України (BBP), 1997, No. 24, ст.170. (n.d.). Access on the internet: https://zakon.rada. gov.ua/laws/show/280/97.

Закон України „Про особливості здійснення права власності у багатоквартирному будинку“. Відомості Верховної Ради України (ВВР), від 14.05.2015, No. 417-VIII. (n.d.). Access on the internet: https://docs.dtkt.ua/doc/417-19.

DOI: $10.7862 / \mathrm{rz} .2021 . \mathrm{mmr} .10$

The text was submitted to the editorial office: April 2021.

The text was accepted for publication: June 2021. 
